\title{
Web Sitesi Tasarım Özelliklerinin Web Site Performansı Üzerindeki Etki Düzeylerinin İncelenmesine Dair Deneysel Bir Çalışma*
}

$\ddot{\mathbf{O} z}$

Çalışma, web site performansı üzerinde web site tasarım özelliklerinin etki düzeylerinin olup olmadı̆̆ının belirlenmesini amaçlamaktadır. Bu amaçla, Hitit Üniversitesi’nin web sitesi üzerinde deneysel bir analiz gerçekleştirilmiştir. Analize, Hitit Üniversitesi web sitesini aktif kullanan 30 Erkek ve $30 \mathrm{Klz}$ öğrenci katılmıştır. Deneyde öğrencilerin online ortamda web sitesini 25 sn. boyunca gezinmeleri să̆lanmış olup bu esnada göz izleme cihazı ile öğrencilerin göz bebeklerinden zaman bazlı sayısal veriler elde edilmiştir. Göz izleme cihazından deneye katılanların göz bebeği hareketleri aracılığıyla elde edilen sayısal verilere ilişkin analizler sonucunda, web site tasarım özelliklerinin, web sitesinin ilk görüntülenme, ortalama odaklanma, tekrar görüntülenme, ortalama tekrar görüntülenme ve toplam görüntüleme itibariyle web site performansı üzerinde olumlu etki sağladı̆̆ belirlenmiştir.
\end{abstract}

Anahtar Kelimeler: Nörogörüntüleme, web site, göz izleme, Hitit Üniversitesi, web site performansi.

\section{An Experimental Study on the Effects of Website Design Features on Website Performance}

\begin{abstract}
The study aims to determine whether the effect levels of website design features on website performance. For this purpose, an experimental analysis was carried out on the website of Hitit University. 30 male and 30 female students who actively use the Hitit University website participated in the analysis. In the experiment, the students' web site in the online environment for 25 seconds. During this time, time-based numerical data were obtained from the pupils of the students with an eye tracking device. As a result of the analysis of the numerical data obtained from the eye tracking device through the pupil movements of the participants, it was determined that the web site design features had a positive effect on the web site performance in terms of first view, average focus, re-views, average re-views and total views.
\end{abstract}

Keywords: Neuroimaging, website, eye tracking, Hitit University, website performance.

\footnotetext{
* Bu çalışma 3-5 Mayıs 2018 tarihleri arasında Çorum Hitit Üniversitesinde gerçekleştirilen Uluslararası Stratejik Araştırmalar Kongresi ISRC 2018'de sunulan bildirinin genişletilmiş halidir.

** ORCID Prof. Dr., Hitit Üniversitesi, İşletme Bölümü, sabihakilic@hitit.edu.tr

*** ORCID Dr. Öğr. Üyesi, Hitit Üniversitesi, İşletme Bölümü, kmugedaldal@hitit.edu.tr
} 


\section{Extended Abstract}

In this study, it is aimed to determine the effect of website design features on website performance. The basic assumption of the study is that website design features affect website performance. In the study, eye tracking method, which is one of the neuroimaging techniques within the scope of neuroscience, was used. Experimental method was used in the study. The experiment was carried out online.

A total of 60 students, 30 girls and 30 boys, who are studying at Hitit University and actively using the Hitit University website, participated in the study voluntarily. Participants were asked to browse the Hitit University website online for 25 seconds in March and April 2016. While the participants were browsing the website, pupil movements were recorded with the Gazepoint eye tracking device.

The eye tracking technique is a method used to provide information about where, how long and how many times users look, and where their current and past attention is focused. This technique is applied either with a well-equipped eye-tracking glasses or by means of devices that track the pupils of the users, called desktop eye-tracking devices.

Website designs are made by institutions by experts in their fields. However, there is a need for objective data on which areas of the designed websites are watched, seen and noticed by the target audience at what level. In fact, it is a necessary information to determine the degree of suitability for the real purpose of how many people view the parts of a website that is thought to be perfectly designed, or whether they are viewed again or not. For example, infrastructure investments made by universities in the digital library can serve their purpose when the access level to library databases is high. However, whether the library link is viewed by the students on the university website, how many students view it, the time it is viewed again, the average focus time indicating whether it attracts the attention of the students, are the information needed to determine the location of the library tab in a visible area in the website design. For this reason, it would be beneficial to analyze the level of performance, which is the degree of fitness for purpose, in web site designs of all institutions, whether private or public, and whether the messages and contents intended to be conveyed to the target audience reach the target audience by using neuroimaging techniques.

In this context, Hitit University website performance analysis was carried out using eye tracking technique, one of the neuroimaging methods. In the experimental analysis carried out in March and April 2016, the current website design was carried out by having the same subject group watch and navigate online at one month intervals. As a result of the analysis, the university's website performance was evaluated in terms of existing and changed designs, and it was concluded that the website design has a significant effect on the website performance according to the students' first view, re-view, number of viewers, average viewing and average focus time data. The study data supports the basic assumption of the study, which states that website design features affect website performance. The study has a unique value in terms of performing website performance measurement online. 


\section{Giriş}

Günümüzde en büyük zenginlik bilgi zenginliğidir. İnsanlar zaman ve ulaşım maliyetlerini göz önünde bulundurarak doğru bilgiye en hızlı şekilde ulaşmak istemektedirler. Bilgisayar ve internet teknolojilerinin gelişmesi insanlara bilgiye hızlı bir şekilde erişim imkânı sunmaktadır. Kuruluşlar insanların bilgiye erişim ihtiyacını en hızlı şekilde karşılayabilmek için bu teknolojiden uzak kalamamışlardır. Bu doğrultuda bireylere kurumlarla ilgili bilgilere erişim imkânı sunan web siteleri önemli bir aktör haline gelmiştir. Kurumlar web sitelerini tasarlamak ve kullanıcılarına ulaştırmak için büyük maliyetlere katlanmaktadır, ancak bu sitelerin bir kısmının kurum hedeflerine ulaşmasında yeterli olmadığı görülmektedir. Yapılan bazı çalışmalar bu yetersizliklerin kötü web sitesi dizaynından kaynaklandığı göstermektedir (Hausman ve Siekpe, 2009: 5).

Web sitesi tasarımında kullanılan yazı tipi, yazı ve arka plan rengi, animasyonlu görseller ve etkileşim özelliklerinin kullanıcıların ruh hallerini ve sitede geçirdikleri süreyi etkilediği düşünülmektedir (Ha ve Im, 2012: 81). Web siteleri kullanıcılara bir deneyim yaşattıklarından dolayı internette kullanılan bilgilerin ve grafik tasarımın kullanıcı deneyimi üzerinde etkisi oldukça büyüktür. Web sitesini, "bir kurumun ya da bir işletmenin kullanabileceği etkili bir pazarlama aracı olarak kullanıcılarına iletmek istediği mesajları yazılı ve görsel unsurlar aracılığıyla ulaştırabilecekleri dijital ortamlardır" şeklinde tanımlamak mümkündür (Cyr ve Bonanni, 2005: 568).

Web site tasarımı bilgi, navigasyon ve grafik tasarımı olarak üç boyuttan oluşturmaktadır. Bilgi tasarımı kullanıcılara iletilen bilgilerin doğru ve yanlışlığını ifade etmektedir. Web site tasarımının ikinci boyutu olan grafik tasarımı ise denge, estetik, renkler, düzen, animasyonlar, fotoğraflar gibi görsel unsurları içermektedir. Navigasyon tasarımı ise kullanıcıların web sitesi içerisindeki gezinmesine yardımcı olan yönlendirici unsurları temsil etmektedir (Cyr, 2008; Ganguly vd. 2010: 305).

Kurumlara ve işletmelere ait web siteleri ses, görüntü, metin vb., bilgilere ulaşım olanağ1 sağlamasından dolayı geleneksel iletişim araçlarına kıyasla daha geniş kitlelere daha az maliyetle erişim imkânı vermektedir (Okay ve Güçdemir, 2011: 166). Bilgi sunmak, reklam ve pazarlama faaliyetlerini gerçekleştirmek, hedef kitleyle çift yönlü iletişim kurabilmek için tasarlanan web sitelerinde genellikle aşağıda sıralanan bilgilere yer verilmektedir (Tarhan, 2007: 78):

- Kuruluşun tarihçesi ve genel tanıtım bilgileri,

- Kurum yöneticilerine ilişkin tanıtıcı bilgi,

- Kuruluşun organizasyon yapısı hakkında bilgiler,

- Kuruluşun faaliyet alanları hakkında bilgiler,

- Yapılan halkla ilişkiler faaliyetlerinin duyurulması,

- Yüklenmesi için sayfaya konulan fotoğraf ve grafikler,

- Yapılan hizmetler hakkında bilgi verilmesi,

- Yapılan çalışmalara ilişkin faaliyet raporlarının yayımlanması vb.

Üniversitelerin web sitelerinde yukarıda yer alan kurum ve işletmelerin web sitelerinde bulunması gereken bilgilere ek olarak bilimsel yayınlar, öğrencilere, akademik ve idari personele yönelik duyurular, üniversite etkinliklerine ilişkin haberler, öğrenci bilgi sistemi, gibi uygulamalara da yer verilmektedir. Ayrica web sitelerinde kurum logosu, kurum ismi, iletişim bilgileri gibi kuruma ilişkin tanıtıcı görsel ve metinlerin de yer alması önem taşımaktadır (Koç, 2015: 61). Çalışmada Hitit Üniversite Web sitesi performansı nörogörüntüleme tekniklerinden göz izleme yöntemi ile analiz edilmektedir. $\mathrm{Bu}$ nedenle 
çalışmanın bir sonraki bölümünde eğitim kurumlarının ve üniversitelerin web site performanslarına ilişkin literatür taraması yer almaktadır.

\section{2. Üniversitelerin Web Site Performansına İlişkin Literatür Taraması}

Literatürde kurumların web site performanslarına ve kullanılabilirliklerine ilişkin çok sayıda çalışma bulunmaktadır. Bu çalışmalarda web sitelerinde bulunması gereken temel özelliklerin neler olması gerektiği, kullanıcıların ihtiyaçlarının nasıl karşılanabileceğine ilişkin sorulara yanıtlar aranmıştır. Aşağıda web site performansına ilişkin literatürde yer alan bazı çalışmalar yer almaktadır:

Suleiman ve Loai (2008) Ürdün Üniversite'sinin web sitelerinin kullanılabilirliklerinin değerlendikleri çalışmalarında anket ve web sayfası analizi tekniklerinden yararlanmışlardır. Çalışma sonucunda üniversite web site kullanılabilirlik performanslarının yeterli düzeyde olduğu ancak kullanıcıların web site erişimine yönelik tatmin düzeylerinin artırılmasına yönelik çeşitli geliştirmelerin yapılması gerektiği sonucuna ulaşmışlardır.

Soummakie ve Talay (2020) Türkiye'deki Üniversitelerin iletişim ve araştırmaları açısından verimlilik ve performanslarını ölçümlemeyi amaçladıkları çalışmalarında üniversitelerin web sitelerinden elde ettikleri verileri, veri zarflama tekniği kullanarak analiz etmişlerdir. Çalışma sonucunca üniversitelerin web sitelerine olan ilgi düzeyinin artırılması ve web site ziyaretçilerinin daha uzun süre zaman geçirmelerini sağlamak için çeşitli düzenlemeler yapılması gerektiğini ifade etmişlerdir.

Abant İzzet Baysal Üniversite'sinin öğrenciler açısından kullanılabilirlik düzeyinin incelendiği diğer bir çalışmada "Website Analysis and Measurement Inventory" ölçeği kullanılarak anket tekniği ile veri seti oluşturulmuştur. Yapılan analizler sonucunda öğrencilerin bölümleri, cinsiyetleri ve bilgisayar dersi alıp almama durumlarına göre üniversitelerinin web sitelerinden beklentilerinin farklılaştığı görülmüştür. Ayrıca çalışmada web sitesinde gezinme sırasında karşılaşılan zorlukların ortadan kaldırılmasının web site performansını artıracağı sonucuna ulaşılmıştır (Ateş ve Karacan, 2010).

Koç'un 2015 yılında gerçekleştirdiği çalışmasında devlet ve vakıf üniversitelerinin web site performanslarını ve tanıtım amaçlı web sitelerini nasıl kullandıklarını içerik analizi yönteminden faydalanarak kıyaslamayı amaçlanmıştır. Çalışmada 3 devlet ve 3 vakıf üniversitenin web siteleri içerik analizi yöntemiyle incelenmiştir. Çalışma sonucunda devlet üniversitelerinin web site performanslarının erişebilirlik, gezilebilirlik, güncellik ve görülebilirlik kriterlerinin vakıf üniversitelerin web sitelerinden daha üstün olduğu sonucuna ulaşılmıştır. Çalışmada ayrıca web sitelerinin tanıtım amaçlı ve kurumsal iletişim açısından devlet üniversitelerinin web site performanslarının daha yüksek düzeyde olduğu tespit edilmiştir.

Özçelik vd., (2006), üniversitelerin web site kullanılabilirlik düzeylerini, 16 katılımcının 4 farklı üniversitenin web sayfasında farklı bilgileri ne kadar sürede, hangi başarı oranında bulduklarını ve bu süreçteki örüntülerini göz izleme tekniği ile analiz etmişlerdir. Göz izleme tekniği ile elde edilen verilerin incelenmesi sonucunda katılımcılara verilen görevlerin ve üniversitelerin web site tasarımlarının web site kullanıcıları üzerinde etkili olduğu sonucuna ulaşılmıştır.

Northern Illinois Üniversitesi Kütüphanesi web sitesinin kullanılabilirliğinin incelendiği çalışmada, web site performansı anket, odak grup görüşmeleri ve kütüphane web sitesinin analizi ile ölçümlenmeye çalışılmıştır. Elde edilen bilgilerin değerlendirilmesi sonucunda anket tekniğinin web site performans ölçümünde diğer iki yönteme kıyasla daha zayıf bulunduğu 
ifade edilmiştir. Çalışmada elde edilen verilere göre kütüphane web sitesinin performansının yükseltilmesi için web site tasarımının gözden geçirilmesi, bilgiye erişim için yönlendirici ve yardımcı unsurların kullanılması gerektiği sonucuna ulaşılmıştır (VandeCreek, 2005). Üniversite kütüphaneleri web sitelerinin incelendiği diğer bir çalışma 2007 yılında Maryland Üniversitesi Kütüphanesi web sitesi üzerinde gerçekleştirilmiştir. Bu çalışmada Maryland Üniversitesinde farklı bölümlerde eğitim görmekte olan dört öğrenciye web sitesi üzerinden farkl1 görevler verilmiş ve bu görevleri yerine getirmeleri istenmiştir. Test sonucunda katılımcıların web sitesini gezerken karşılaştıkları sorunlar tespit edilmiştir (University of Maryland, 2007).

Yapılan litaretür araştırması sonucunda, web site performans analizlerinin çeşitli yöntemlerle gerçekleştirildiği görülmektedir. $\mathrm{Bu}$ yöntemlerden bir tanesi Göz İzleme yöntemidir. Göz İzleme yöntemiyle web site performansı ölçümlenirken genellikle katılımcılara bir görev verilmiş ve bu göreve erişimde katılımcıların karşılaştıkları engeller üzerinde durulmuştur. Bu çalışmada Hitit Üniversitesi web sitesi performansı göz izleme yöntemiyle analiz edilmiştir ancak literatürde yer alan diğer çalışmalardan farklı olarak katılımcılardan web sitesi üzerinde online olarak gezinmeleri istenmiştir. Bu gezinme esnasında katılımcıların web sitesinde en çok odaklandıkları yerler tespit edilmiş ve bu tespitler doğrultusunda yeni bir web sitesi tasarımı gerçekleştirilerek iki web site modeli arasında kıyaslama yapılmıştır. $\mathrm{Bu}$ anlamda çalışmanın yöntemi ve uygulanma biçimi açısından çalışmanın özgün bir değer taşıdığını söylemek mümkündür. Aşağıdaki bölümde çalışmanın amacı ve kapsamında elde edilen bulgular yer almaktadır.

\section{Yöntem}

$\mathrm{Bu}$ çalışmada, web sitesi tasarım özelliklerinin web sitesi performansı üzerindeki etkisinin belirlenmesi amaçlanmaktadır. Çalışmanın temel varsayımı web sitesi tasarım özelliklerinin web sitesi performansını etkilediğidir. Çalışmada nörobilim kapsamında nörogörüntüleme tekniklerinden olan göz izleme yöntemi kullanılmıştır. Çalışmada deneysel yöntemden yararlanılmıştır. Deney online ortamda gerçekleştirilmiştir.

Çalışmaya Hitit Üniversitesi’nde eğitim gören ve Hitit Üniversitesi web sitesini aktif kullanan $30 \mathrm{k}$ 1z ve 30 erkek olmak üzere toplam 60 öğrenci gönüllü olarak katılmıştır. Katılımcılardan 2016 y1lı Mart ve Nisan aylarında Hitit Üniversitesi web sitesinde 25 saniye süresince online olarak gezinmeleri istenmiştir. Katılımcılar web sitesinde gezinirken göz bebeği hareketleri Gazepoint göz izleme cihazı ile kayıt altına alınmıştır. Deney beyaz renge boyalı ve sessiz bir oda ortamında gerçekleştirilmiş, deneye katılan öğrencilerin dış etkenlere mümkün olduğunca az maruz kalmaları sağlanmıştır.

Göz İzleme yöntemi, kullanıcıların nereye, ne kadar süreyle ve kaç kez baktığına, anlık ve geçmiş dikkatinin nerelere yoğunlaştığına ilişkin bilgi sağlamak için kullanılan bir yöntemdir. Bu teknik ya donanımlı bir göz izleme gözlüğü ile ya da masa üstü göz izleme cihazı adı verilen kullanıcıların göz bebeği hareketlerini takip eden cihazlar aracılığıyla uygulanmaktadır.

Göz İzleme yöntemi sonucunda;

- Hareketli Nokta Haritas1

- Is1 Haritas1

- Saydam Harita elde edilmiştir.

Göz İzleme yöntemiyle web sitesine ilişkin aşağıda belirtilen anlık veriler elde edilmektedir; 
- Görüntüleyen Kişi Sayıları

- İlk Görüntülenme Saniyeleri

- Ortalama Odaklanma Süreleri

- Tekrar Görüntüleyen Kişi Sayıları

- Ortalama Tekrar Görüntülenme Saniyeleri

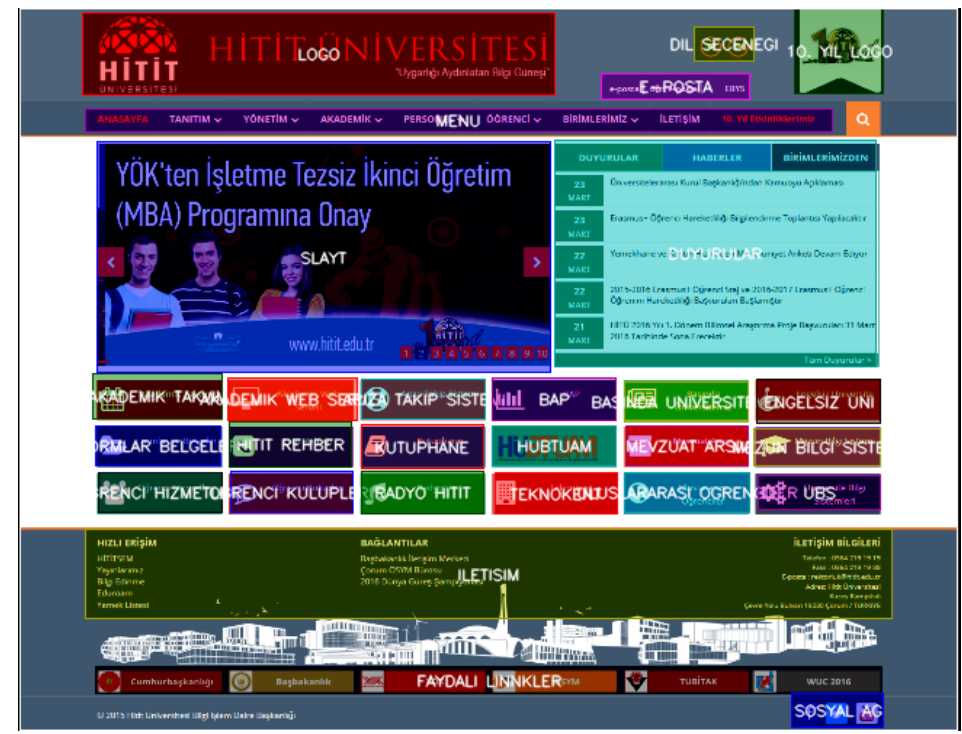

Şekil 1. İlgi Alanları

Şekil 1'de katılımcıların gözbebeklerinden alınacak olan sayısal verilere ilişkin ilgi alanları yer almaktadır. Sayısal veri alınması düşünülen alanlar deney öncesinde belirlenmekte ve göz izleme cihazı bu alanlara ilişkin gözbebeği hareketlerine ilişkin zaman bazlı sayısal veri sağlamaktadır.

Deney tasarımında, 2016 yılı Mart ayında yapılan web site analizine göre 2016 yılı Nisan ayında analiz öncesinde bazı linklerin yerleri website performansını değerlendirmek üzere değiştirilmiştir. Yerleri değiştirilen bu linkler aşağıdaki gibidir:

- Logo

- Slayt

- Duyuru/Haberler/Birimlerimizden

- Üniversite Bilgi Sistemi (Übs)

- Mezun Bilgi Sistemi

- Basında Üniversitemiz

- Bap

- Radyo Hitit

- Teknokent

- Hitit Rehber

Web site tasarım özelliklerinin hangisinin daha fazla görüntülendiği katılımcıların göz hareketleri neticesinde belirlenmiştir. Katılımcılardan web sitesini 25 sn incelemeleri istenerek göz izleme cihazı ile katılımcıların göz hareket verileri elde edilmiştir. Aşağıdaki şekillerde katılımcıların web site tasarım özelliklerini görüntüleme sayıları yer almaktadır. 


\section{GÖRÜNTÜLEYEN KIŞi SAYILARI}

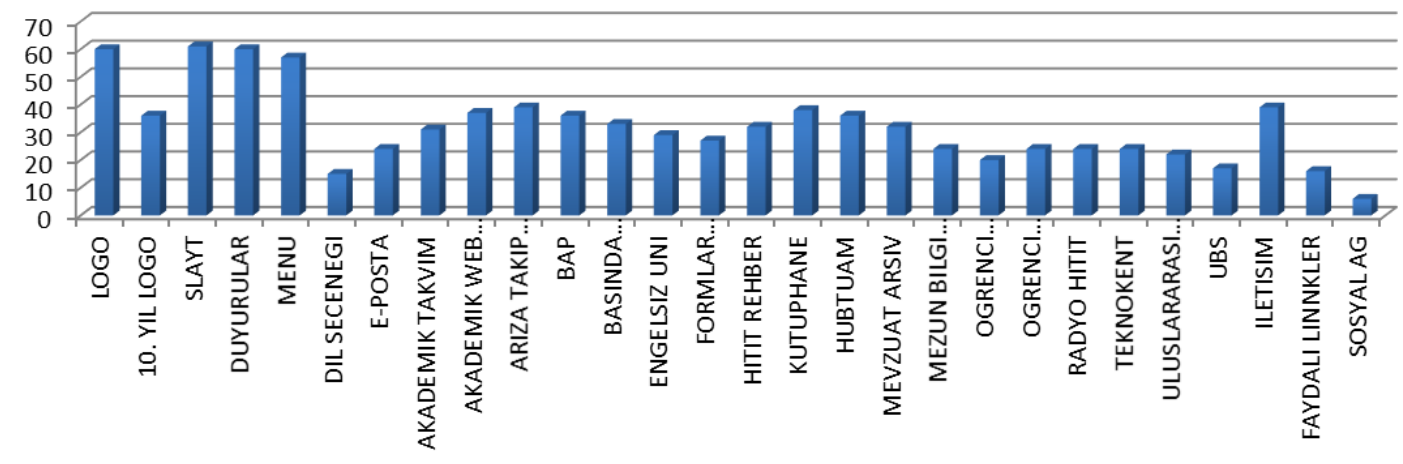

Şekil 2. 2016 yılı Mart Ayı Görüntüleyen Kişi Sayıları

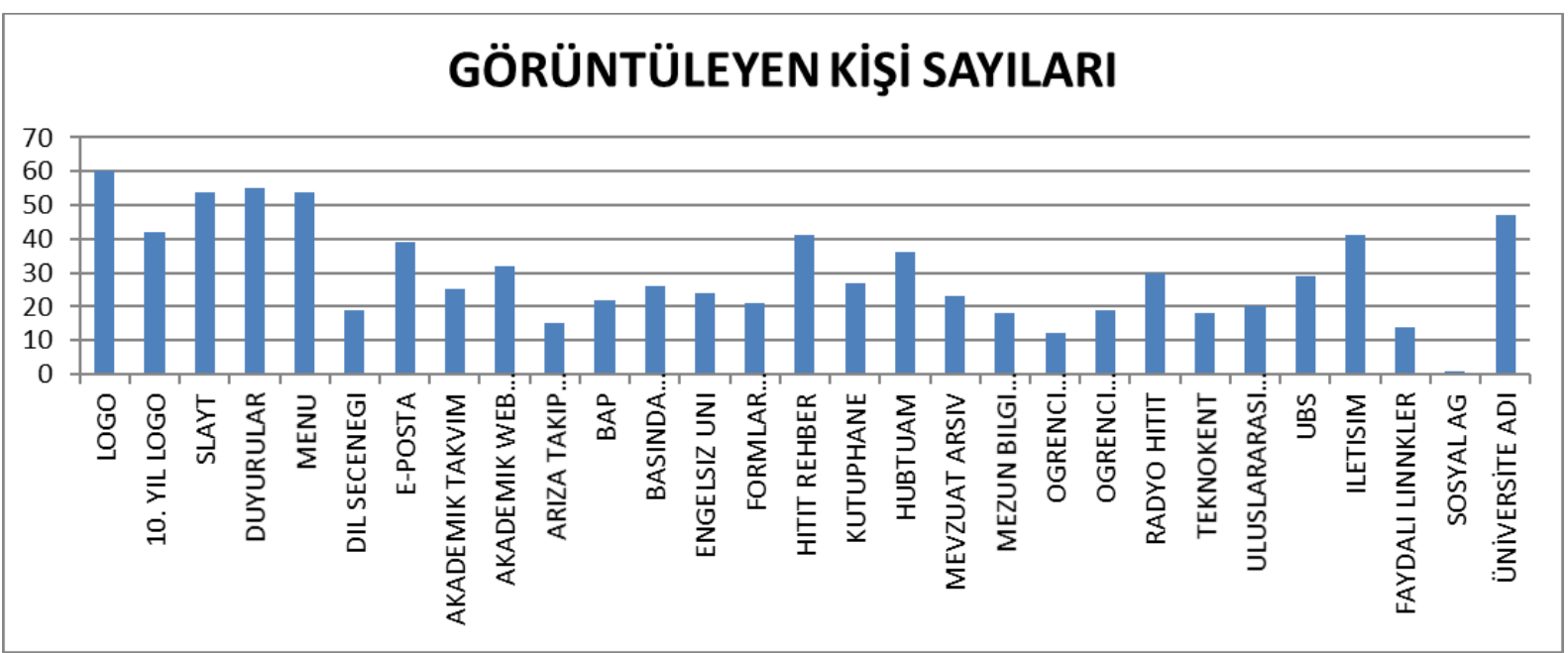

Şekil 3. 2016 yılı Nisan Ayı Görüntüleyen Kişi Sayıları

Şekil 2 ve 3 incelendiğinde ilk web sitesi tasarımında 60 katılımcıdan neredeyse hepsinin logo, slayt ve duyurular sekmelerini görüntüledikleri anlaşılmaktadır. Yapılan değişiklikler sonucunda ikinci web sitesi tasarımında ise logoyu görüntüleyen kişi sayılarının artış gösterdiği ayrıca daha fazla sayıda katılımcının menü sekmesini görüntülediği de görülmektedir. Ayrıca ikinci web site tasarımında eklenen üniversite adı görselinin çok sayıda katılımcı tarafından görüntülendiği görülmektedir. Aşağıdaki grafiklerde 2016 yılı Mart ve Nisan aylarında yapılan deneysel çalışmada katılımcıların web site tasarım özelliklerini ilk görüntülenme saniyeleri yer almaktadır. 


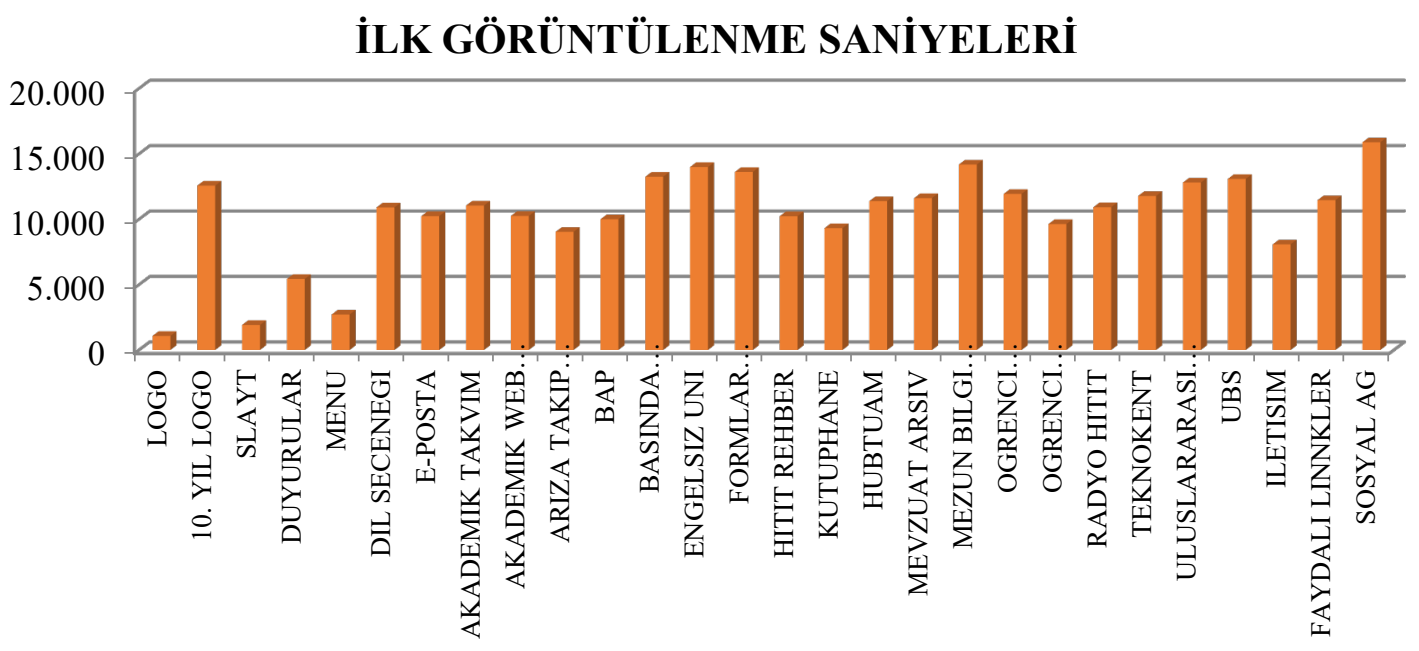

Şekil 4. 2016 yılı Mart Ayı İlk Görüntülenme Saniyeleri

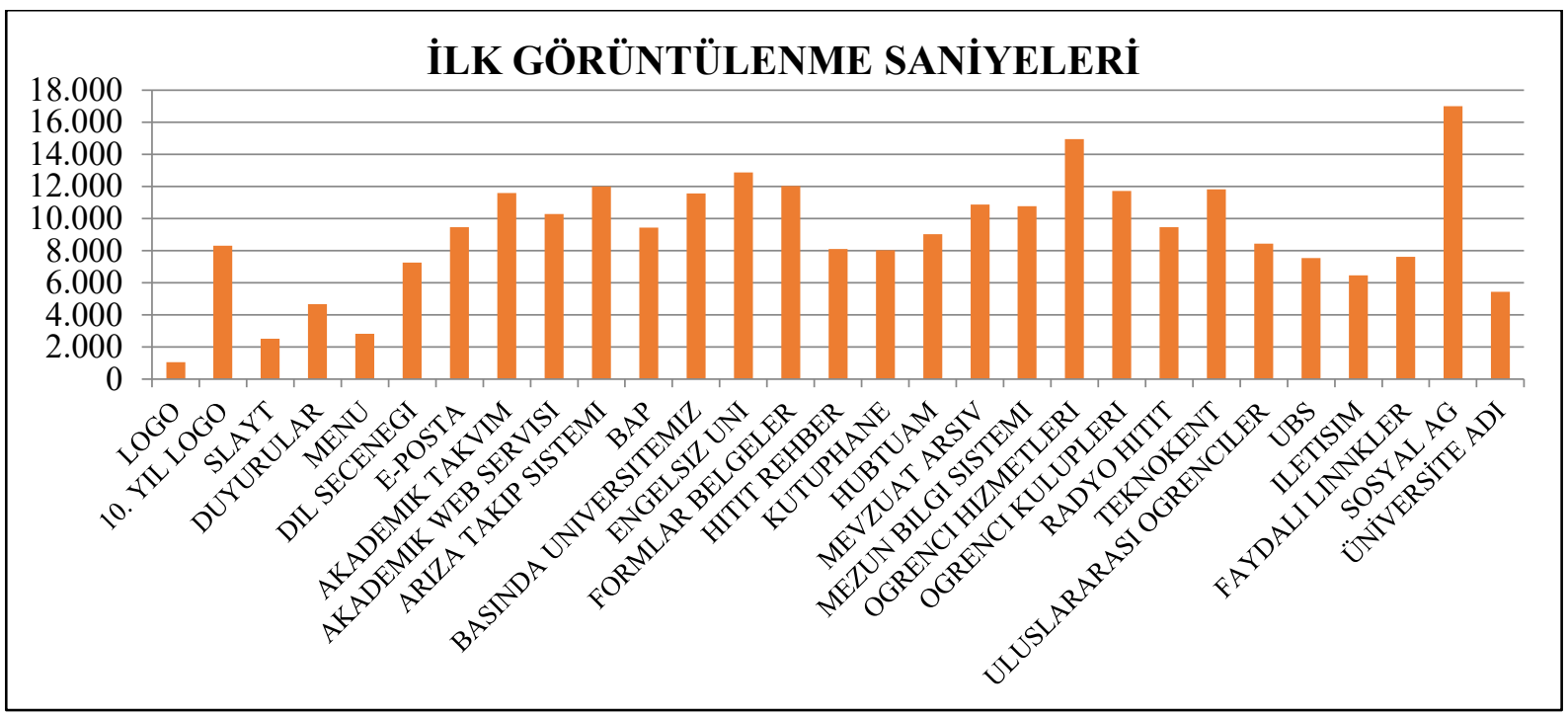

Şekil 5. 2016 yılı Nisan Ayı İlk Görüntülenme Saniyeleri

Aşağıdaki şekillerde katılımcıların web sitesi tasarım özelliklerine ilişkin ortalama odaklanma saniyeleri yer almaktadır. 


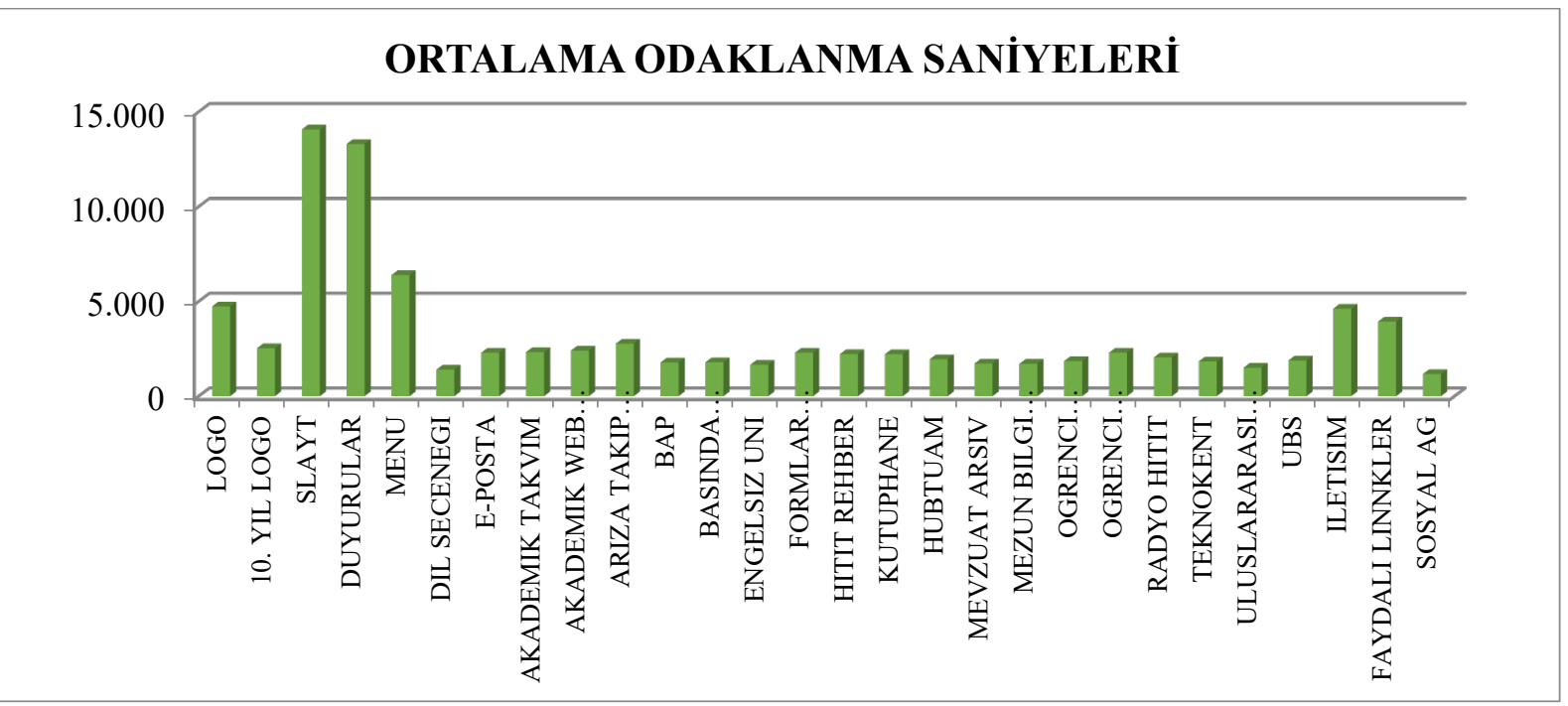

Şekil 6. 2016 yılı Mart Ayı Ortalama Odaklanma Saniyeleri

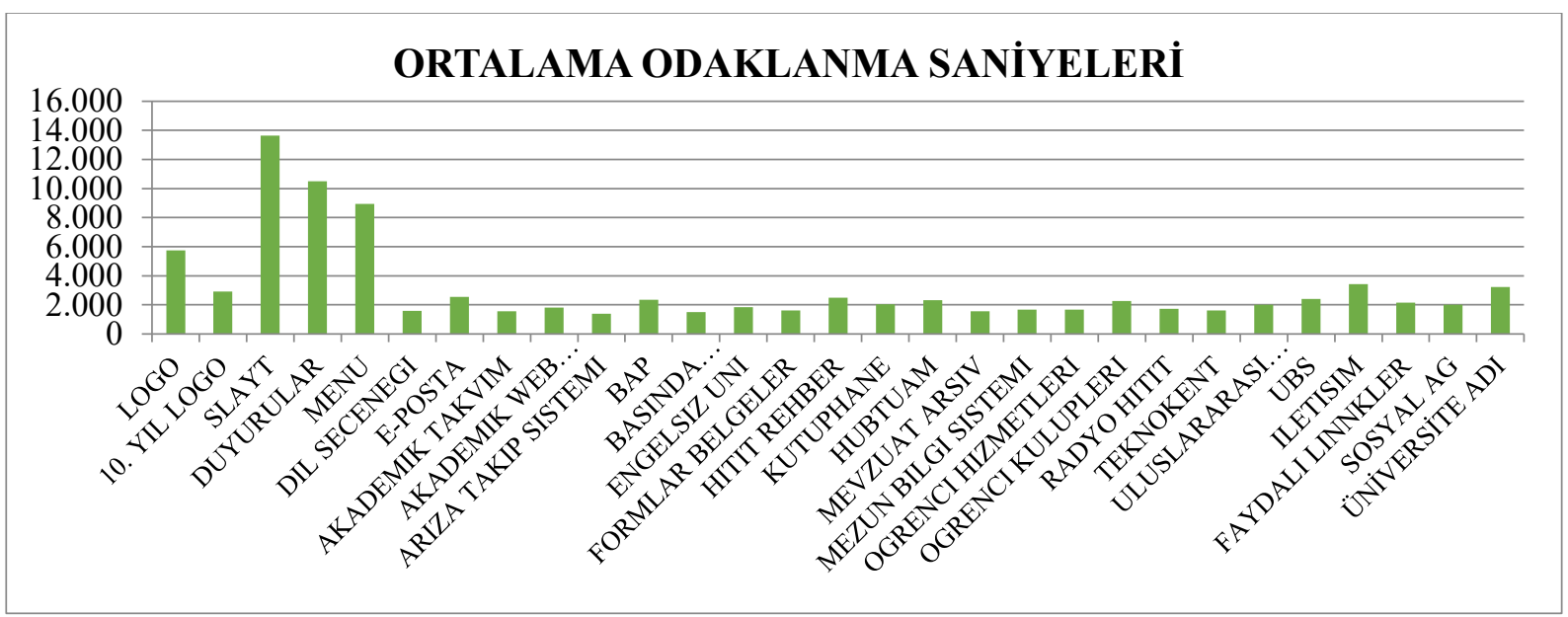

Şekil 7. 2016 yılı Nisan Ayı Ortalama Odaklanma Saniyeleri

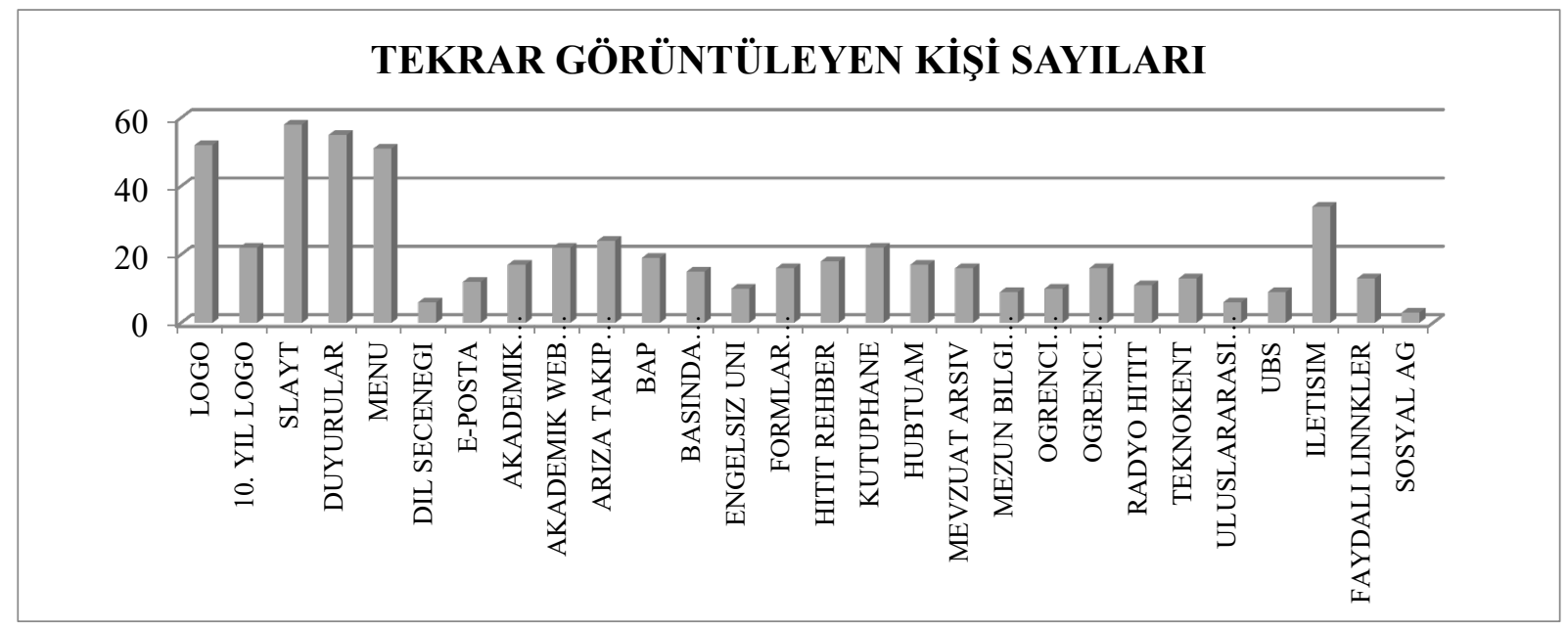

Şekil 8. 2016 yılı Mart Ayı Tekrar Görüntüleyen Kişi sayıları 


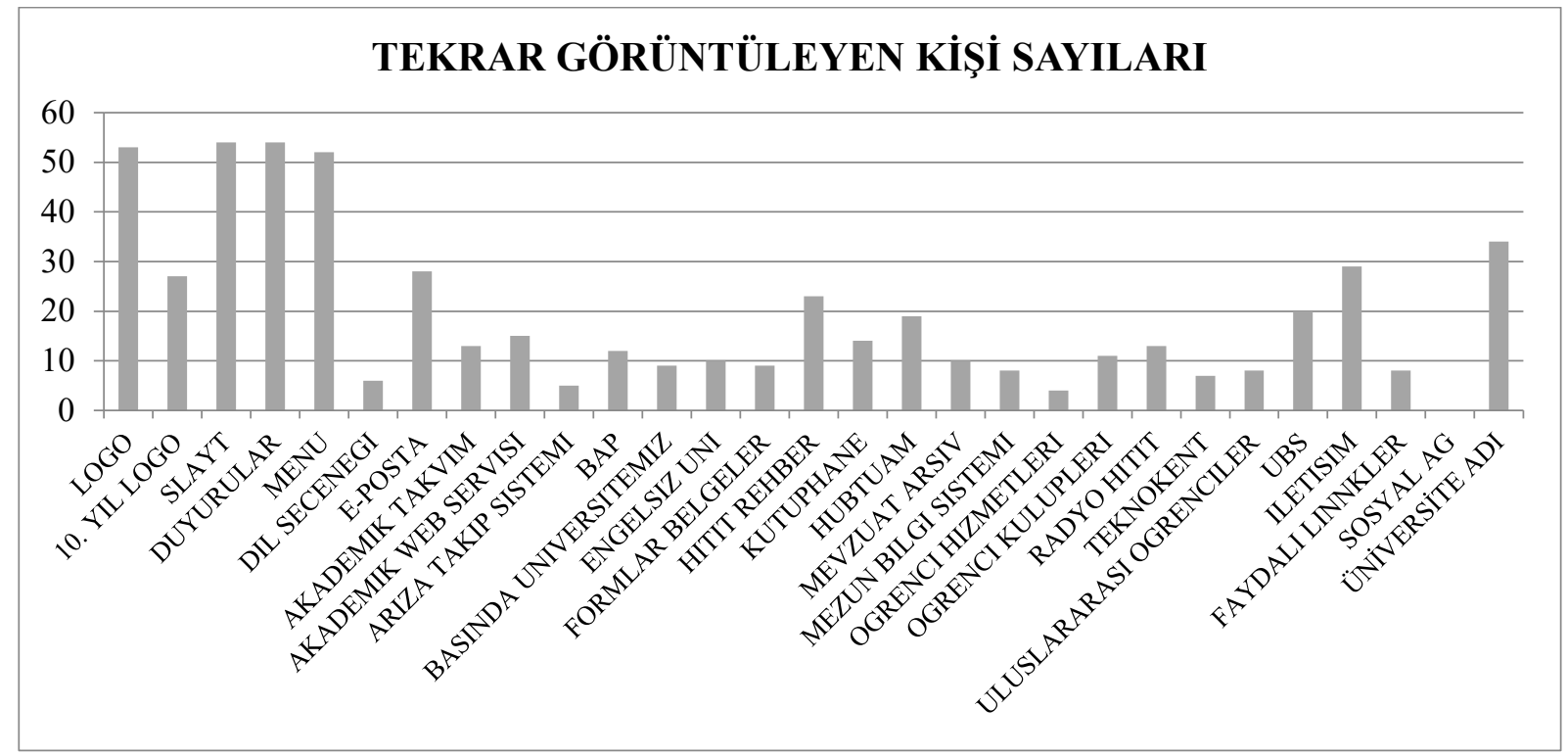

Şekil 9. 2016 yılı Nisan Ayı Tekrar Görüntüleyen Kişi sayıları

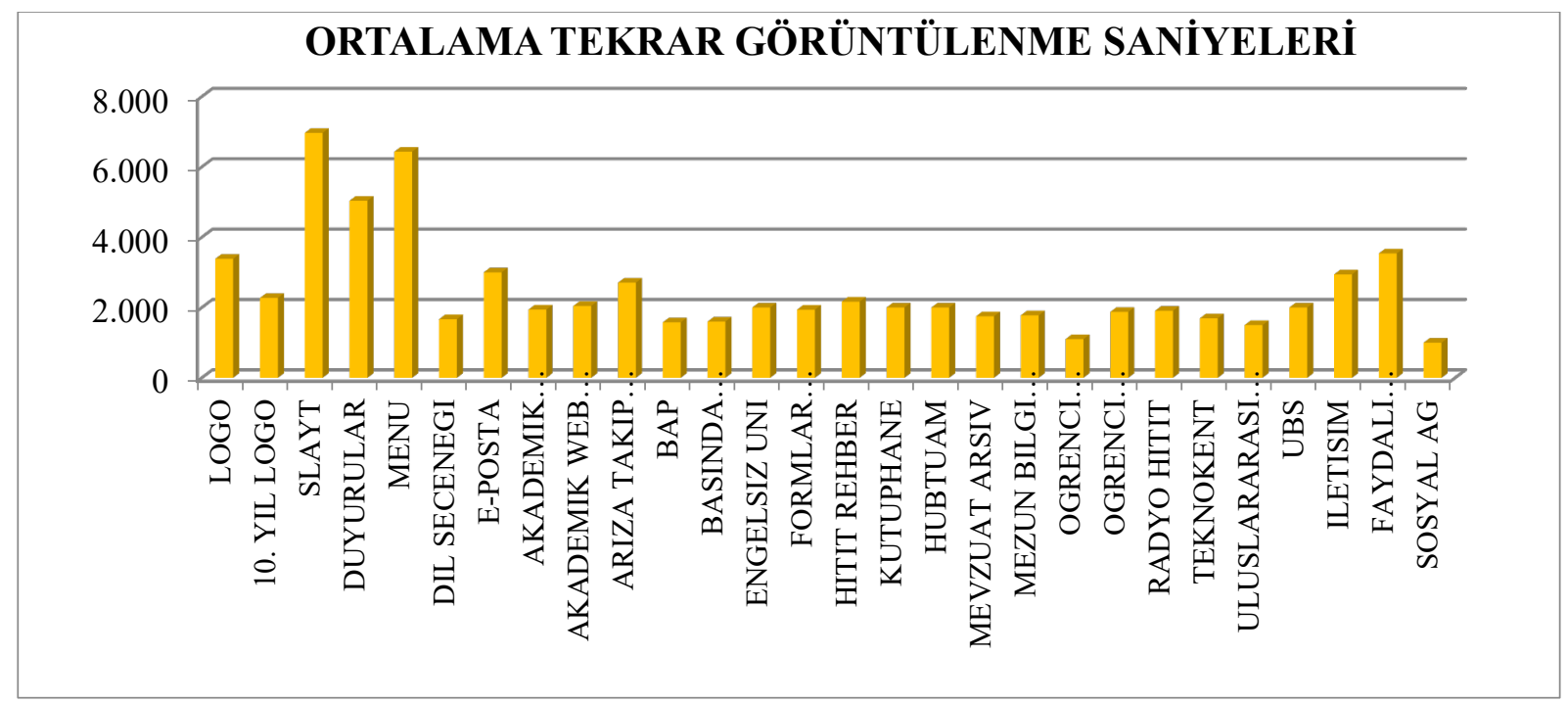

Şekil 10. 2016 yılı Mart Ayı Ortalama Tekrar Görüntüleme Saniyeleri

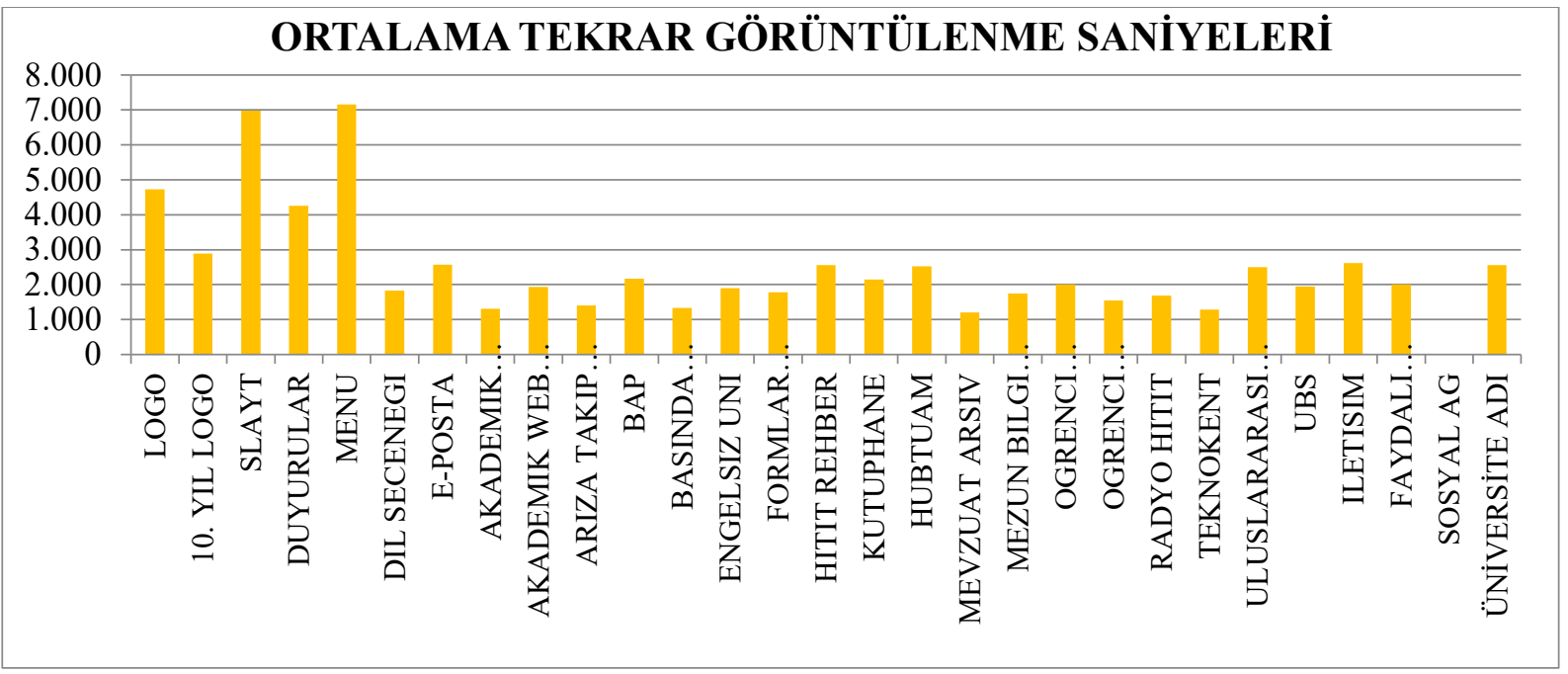

Şekil 11. 2016 yılı Nisan Ayı Ortalama Tekrar Görüntülenme Saniyeleri 
Yukarıdaki şekillerde yer alan 2016 y1lı Mart ayında 60 öğrencinin katılımıyla gerçekleştirilen 25 sn'lik analiz sonuçlarıyla 2016 yılı Nisan ayında yine 60 öğrencinin katılımıyla gerçekleştirilen 25 sn'lik analiz sonuçlarına ilişkin karşılaştırmalı sonuçlar aşağıdaki tabloda özetlenmektedir:

Tablo 1. 2016 Mart ve 2016 Nisan Aylarında Gerçekleştirilen Analizlerin Karşılaştırılması

\begin{tabular}{|c|c|}
\hline LOGO & $\begin{array}{l}2016 \text { Y1lı Mart/Nisan } \\
\text { Değișim \% }\end{array}$ \\
\hline Analiz süresince Logoyu görüntüleyen kiși sayısı & $\mathbf{0}$ \\
\hline Analiz süresince Logonun ilk görüntülenme saniyesi & $+2,7$ \\
\hline Analiz süresince Logoya ortalama odaklanma süresi & $+21,7$ \\
\hline Analiz süresince Logoyu tekrar görüntüleyen kişi sayısı & $+1,9$ \\
\hline Analiz süresince Logonun ortalama tekrar görüntülenme saniyesi & $-39,8$ \\
\hline SLAYT & $\begin{array}{l}2016 \text { Y1lı Mart/Nisan } \\
\text { Değișim \% }\end{array}$ \\
\hline Analiz süresince Slaytı görüntüleyen kişi sayısı & $-11,5$ \\
\hline Analiz süresince Slaytın ilk görüntülenme saniyesi & $-31,9$ \\
\hline Analiz süresince Slayta ortalama odaklanma süresi & -3 \\
\hline Analiz süresince Slaytı tekrar görüntüleyen kişi sayıs1 & $-6,9$ \\
\hline Analiz süresince Slaytın ortalama tekrar görüntülenme süresi & $-0,2$ \\
\hline DUYURU/HABER/BİRIMLERIMIZZEN & $\begin{array}{l}2016 \text { Y1lı Mart/Nisan } \\
\text { Değişim \% }\end{array}$ \\
\hline Analiz süresince Duyuruları görüntüleyen kişi sayıs1 & $-8,3$ \\
\hline Analiz süresince Duyuruların ilk görüntülenme saniyesi & $+14,2$ \\
\hline Analiz süresince Duyurulara ortalama odaklanma süresi & -21 \\
\hline Analiz süresince Duyuruları tekrar görüntüleyen kişi sayıS1 & $-1,8$ \\
\hline Analiz süresince Duyuruların ortalama tekrar görüntülenme saniyesi & $+15,4$ \\
\hline ÜNIVERSİTE BIILGİ SİSTEMİ (UBS) & $\begin{array}{l}2016 \text { Y1lı Mart/Nisan } \\
\text { Değişim \% }\end{array}$ \\
\hline Analiz süresince UBS'ni görüntüleyen kişi sayısı & $+70,6$ \\
\hline Analiz süresince UBS'nin ilk görüntülenme saniyesi & $+42,3$ \\
\hline Analiz süresince UBS'ne ortalama odaklanma süresi & $+28,3$ \\
\hline Analiz süresince ÜBS'ni tekrar görüntüleyen kişi sayısı & $+122,2$ \\
\hline Analiz süresince UBS'nin ortalama tekrar görüntülenme saniyesi & $+2,5$ \\
\hline MEZUN BİLGİ SİSTEMİ (MBS) & $\begin{array}{l}2016 \text { Y1lı Mart/Nisan } \\
\text { Değișim \% }\end{array}$ \\
\hline Analiz süresince MBS'ni görüntüleyen kişi sayıs1 & -25 \\
\hline Analiz süresince MBS'nin ilk görüntülenme saniyesi & +24 \\
\hline Analiz süresince MBS'ne ortalama odaklanma süresi & $-2,4$ \\
\hline Analiz süresince MBS'ni tekrar görüntüleyen kişi sayıs1 & $-11,1$ \\
\hline Analiz süresince MBS'nin ortalama tekrar görüntülenme saniyesi & $+1,6$ \\
\hline BASINDA ÜNIVERSITEMIZ & $\begin{array}{l}2016 \text { Y1lı Mart/Nisan } \\
\text { Değişim \% }\end{array}$ \\
\hline Analiz süresince Basında Üniversitemiz görüntüleyen kişi sayıs1 & $-21,2$ \\
\hline Analiz süresince Basında Üniversitemizin ilk görüntülenme saniyesi & $+12,8$ \\
\hline Analiz süresince Basında Üniversitemize ortalama odaklanma süresi & $-16,1$ \\
\hline Analiz süresince Basında Üniversitemizi tekrar görüntüleyen kişi sayıs1 & -40 \\
\hline $\begin{array}{l}\text { Analiz süresince Basında Üniversitemizin ortalama tekrar görüntülenme } \\
\text { saniyesi }\end{array}$ & $+16,7$ \\
\hline BAP & $\begin{array}{l}2016 \text { Y1lı Mart/Nisan } \\
\text { Değișim \% }\end{array}$ \\
\hline Analiz süresince BAP’1 görüntüleyen kişi sayıs1 & $-38,9$ \\
\hline Analiz süresince BAP'ın ilk görüntülenme saniyesi & $+5,5$ \\
\hline Analiz süresince BAP'a ortalama odaklanma süresi & +33 \\
\hline Analiz süresince BAP’1 tekrar görüntüleyen kişi sayıs1 & $-36,8$ \\
\hline Analiz süresince BAP'ın ortalama tekrar görüntülenme saniyesi & $-37,2$ \\
\hline
\end{tabular}


Tablo 1 (Devamı). 2016 Mart ve 2016 Nisan Aylarında Gerçekleştirilen Analizlerin Karşılaştırılması

\begin{tabular}{|c|c|}
\hline RADYO HITITT & $\begin{array}{c}2016 \text { Y1lı Mart/Nisan } \\
\text { Değișim \% }\end{array}$ \\
\hline Analiz süresince Radyo Hitit’i görüntüleyen kişi sayısı & +25 \\
\hline Analiz süresince Radyo Hitit'in ilk görüntülenme saniyesi & $+13,3$ \\
\hline Analiz süresince Radyo Hitit’e ortalama odaklanma süresi & $-15,1$ \\
\hline Analiz süresince Radyo Hitit’i tekrar görüntüleyen kişi sayısı & $+18,2$ \\
\hline Analiz süresince Radyo Hitit'in ortalama tekrar görüntülenme saniyesi & $+11,4$ \\
\hline TEKNOKENT & $\begin{array}{c}2016 \text { Y1lı Mart/Nisan } \\
\text { Değişim \% }\end{array}$ \\
\hline Analiz süresince Teknokent’i görüntüleyen kiși sayıs1 & -25 \\
\hline Analiz süresince Teknokent'in ilk görüntülenme saniyesi & $-0,3$ \\
\hline Analiz süresince Teknokent'e ortalama odaklanma süresi & $-12,1$ \\
\hline Analiz süresince Teknokent'i tekrar görüntüleyen kiși sayıs1 & $-46,2$ \\
\hline Analiz süresince Teknokent'in ortalama tekrar görüntülenme saniyesi & +24 \\
\hline HITTIT REHBER & $\begin{array}{c}2016 \text { Y1lı Mart/Nisan } \\
\text { Değişim \% }\end{array}$ \\
\hline Analiz süresince Hitit Rehber’i görüntüleyen kişi sayısı & $+28,1$ \\
\hline Analiz süresince Hitit Rehber'in ilk görüntülenme saniyesi & $+20,8$ \\
\hline Analiz süresince Hitit Rehber'e ortalama odaklanma süresi & $+12,1$ \\
\hline Analiz süresince Hitit Rehber’i tekrar görüntüleyen kiși sayısı & $+27,8$ \\
\hline Analiz süresince Hitit Rehber'in ortalama tekrar görüntülenme saniyesi & $-18,4$ \\
\hline
\end{tabular}

Değiştirilen linklerin bir önceki analize göre performans göstergeleri aşağıdaki gibidir.

- Üniversite Bilgi Sistemi linki, toplam görüntüleyen kişi sayısı, ilk görüntülenme saniyesi, ortalama odaklanma süresi, tekrar görüntüleyen kişi sayısı ve ortalama tekrar görüntülenme saniyesi bakımından performans artışı göstermiştir.

- Logo, toplam görüntüleyen kişi sayısında bir değişme olmaz iken, ilk görüntülenme saniyesi, ortalama odaklanma süresi, tekrar görüntüleyen kişi sayısı bakımından performans artışı göstermiştir. Logonun ortalama tekrar görüntülenme saniyesinde 1,347 saniyelik bir gerileme yaşanmıştır.

- Slayt linkinde, toplam görüntüleyen kişi sayısı, ilk görüntülenme saniyesi, ortalama odaklanma süresi, tekrar görüntüleyen kişi sayısı ve ortalama tekrar görüntülenme saniyesi bakımından performans düşüşü yaşanmıştır.

- Duyuru/Haberler/Birimlerimizden linkinde toplam görüntüleyen kişi sayısı, ortalama odaklanma süresi, tekrar görüntüleyen kişi sayısı performansında azalma görülürken, ilk görüntülenme saniyesi ve tekrar görüntülenme saniyesinde performans artışı yaşanmıştır.

- Mezun Bilgi Sistemi linkinde toplam görüntüleyen kişi sayısında, ortalama odaklanma süresinde ve tekrar görüntüleyen kişi sayısında performans düşüşü yaşanırken, ilk görüntülenme saniyesinde ve ortalama tekrar görüntülenme saniyesinde performans artışı yaşanmıştır.

- Basında Üniversitemiz linkinde toplam görüntüleyen kişi sayısında, ortalama odaklanma süresinde ve tekrar görüntüleyen kişi sayısında performans düşüşü yaşanırken, ilk görüntülenme saniyesinde ve ortalama tekrar görüntülenme saniyesinde performans artışı yaşanmıştır.

- BAP linkinde toplam görüntülenme sayısı, tekrar görüntüleyen kişi sayısı, ortalama tekrar görüntülenme saniyesi açısından performans düşüşü yaşanırken, $\underline{\text { ilk }}$ 
görüntülenme saniyesi ve ortalama odaklanma saniyesi bakımından performans artışı göstermiştir.

- Radyo Hitit linkinde, toplam görüntüleyen kiși sayısında, ilk görüntülenme saniyesinde, tekrar görüntüleyen kiși sayısında, ortalama tekrar görüntülenme saniyesinde performans artışı yaşanırken, ortalama odaklanma saniyesinde performans düşüşü görülmüştür.

- Teknokent linkinde, toplam görüntüleyen kişi sayısında, ilk görüntülenme saniyesinde, ortalama odaklanma süresinde tekrar görüntüleyen kişi sayısında performans düşüşü yaşanırken, ortalama tekrar görüntülenme saniyesinde performans artışı yaşanmıştır.

- Hitit Rehber linkinde, toplam görüntüleyen kiși sayısında, ilk görüntülenme saniyesinde, ortalama odaklanma süresinde, tekrar görüntüleyen kiși sayısında performans artışı yaşanırken, ortalama tekrar görüntülenme saniyesinde performans düşüşü yaşanmıştır.

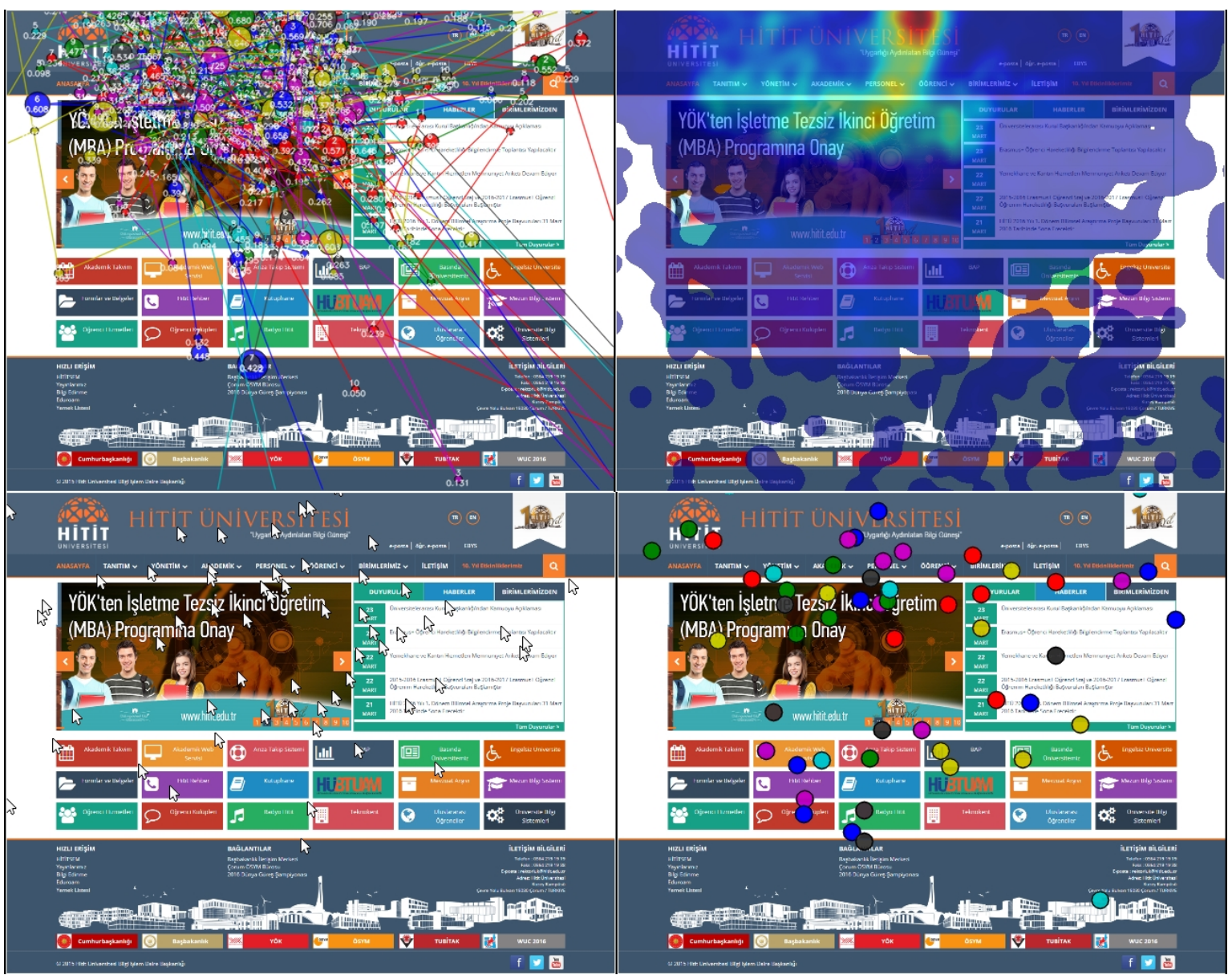

Şekil 12. 2016 yılı Mart Ay1 5. Sn. Görüntüleri 


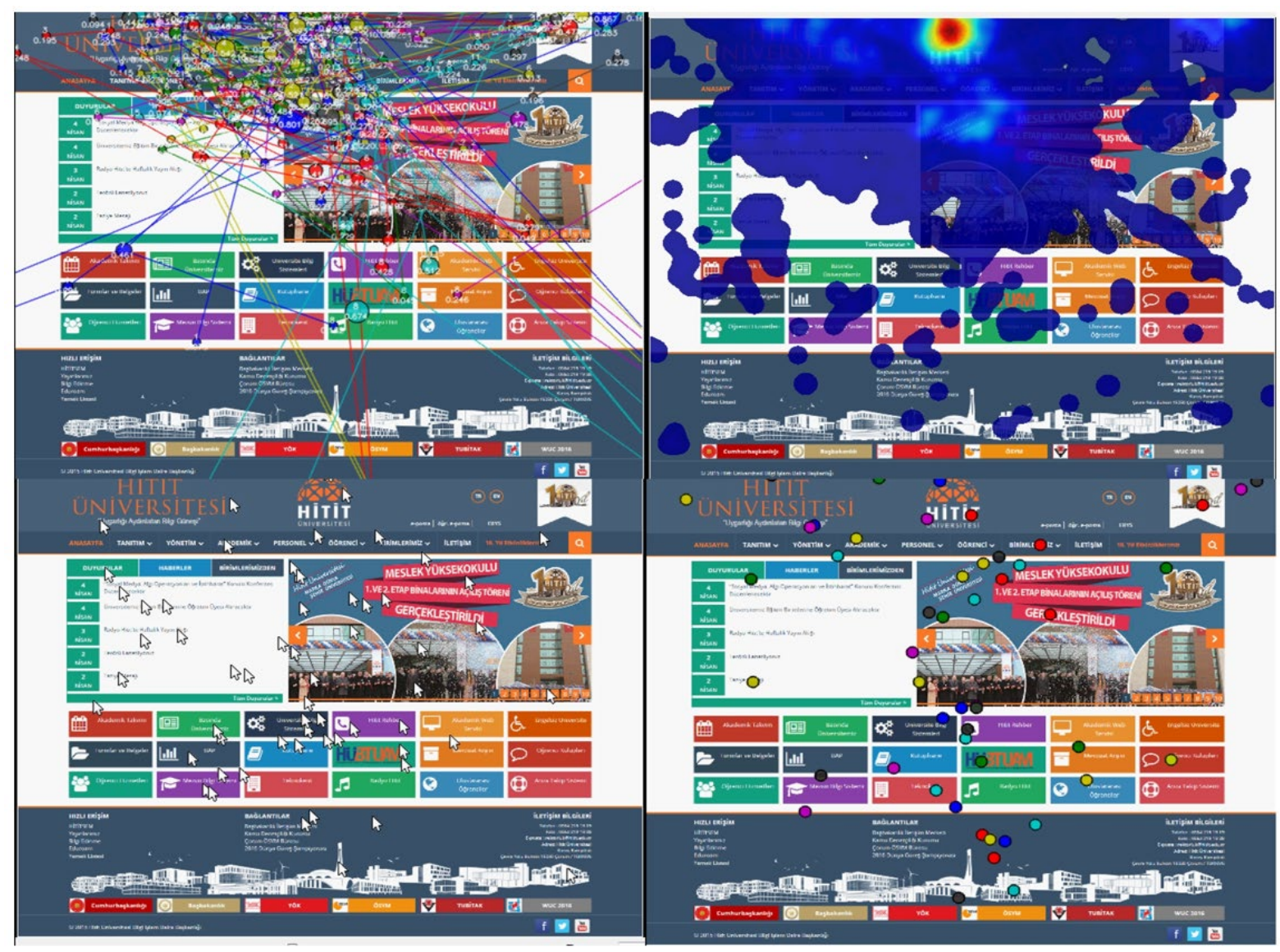

Şekil 13. 2016 yılı Nisan Ayı 5. Sn. Görüntüleri

\section{Sonuç ve Öneriler}

Dijital çağın yaşandığı günümüz dünyasında web siteleri kurumların en etkili iletişim araçlarından biridir. Eğitim hizmeti sunan üniversiteler için de öğrencileri ile etkin iletişim kurabildikleri, gerek haber gerekse duyuru aracılığıyla öğrencilerine bilgi aktarabildikleri önemli mecralardan biri olarak web siteleri büyük önem taşımaktadır. Web siteleri aynı zamanda öğrencilerin dijital kütüphane, veri tabanları, proje birimleri, bölüm etkinlikleri, ders içerikleri, ders programları, not bilgileri, kulüp faaliyetleri ve etkinlikleri açısından doğrudan bilgi alabildikleri dijital bir platformdur. Böyle bir mecranın amacına tam hizmet edip etmediği, bir anlamda performansı hakkında doğru bilgi sahibi olmak öğrencilerle etkileşim açısından da önem taşımaktadır.

Web site tasarımları kurumlar tarafından alanında uzman kişilere yaptırılmaktadır. Ancak tasarlanan web sitelerinin hangi alanlarının hedef kitle tarafından ne düzeyde izlendiği, görüldüğü ve farkına varıldığına dair objektif verilere ihtiyaç duyulmaktadır. Öyle ki mükemmel tasarlandığı düşünülen bir web sitesinin görüntülenmesi istenen bölümlerinin kaç kişi tarafından kaç kez görüntülendiği ya da tekrar görüntülenip görüntülenmediği gerçek amacına uygunluk derecesinin belirlenmesi açısından gerekli bir bilgidir. Örneğin, üniversiteler tarafından dijital kütüphaneye yapılan alt yapı yatırımları, kütüphane veri tabanlarına erişim düzeyi yüksek olduğunda amacına hizmet edebilecektir. Ancak üniversite web sitesi üzerinden kütüphane linkinin öğrenciler tarafından görüntülenip görüntülenmediği, kaç öğrenci tarafından görüntülendiği, tekrar görüntülenme süresi, öğrencilerin dikkatini çekip çekmediğini belirten ortalama odaklanma süresi, web site tasarımında kütüphane sekmesinin görünür bir alanda yerinin belirlenmesi açısından ihtiyaç duyulan bilgilerdir. Bu nedenle özel veya kamu 
olsun tüm kurumların web site tasarımlarında amaca uygunluk derecesi olan performans düzeyinin, bir anlamda hedef kitleye iletilmek istenen mesaj ve içeriklerin ulaşıp ulaşmadığının nörogörüntüleme tekniklerinden yararlanılarak analiz edilmesi fayda sağlayabilecektir.

Çalışmada bu kapsamda, Hitit Üniversitesi web site performans analizi nörogörüntüleme yöntemlerinden göz izleme yöntemi kullanılarak gerçekleştirilmiştir. 2016 yılı Mart ve Nisan aylarında gerçekleştirilen deneysel analizde, mevcut web site tasarımı bir ay arayla aynı denek grubuna online ortamda izlettirilerek ve gezinmeleri istenerek gerçekleştirilmiştir. Analiz sonucunda üniversitenin web sitesi performansı mevcut ve değiştirilen tasarımlar itibariyle değerlendirilmiş olup, öğrencilerin ilk görüntüleme, tekrar görüntüleme, görüntüleyen kişi sayıs1, ortalama görüntüleme ve ortalama odaklanma süresi verilerine göre web site tasarımının web site performansı üzerinde önemli bir etkiye sahip olduğu sonucuna ulaşılmıştır. Çalışma verileri, web sitesi tasarım özelliklerinin web sitesi performansını etkilediğini ifade eden çalışmanın temel varsayımını destekler nitelik taşımaktadır. Çalışma web site performans ölçümünün online ortamda gerçekleştirilmesi açısından özgün değer taşımaktadır.

\section{Kaynakça}

Ateş, V. ve Karacan, H. (2010). Abant İzzet Baysal Üniversitesi web sitesi kullanılabilirlik analizi. Bilişim Teknolojileri Dergisi, 2 (2).

Cyr, D. ve Bonanni, C. (2005). Gender and website design in E-Business. International Journal of Electronic Business, 3(6), 565-582.

Cyr, D. (2008). Modeling web site design across cultures: Relationships to Trust, satisfaction, and e-loyalty. Journal of Management Information Systems, 24(4), 47-72.

Ganguly, B., Dash, S. B., Cyr, D. ve Head, M. (2010). The Effects of website design on purchase intentioni in online shopping: The Mediating role of trust and the moderating role of culture. International Journal of Electronic Business, 8(4-5), 302-330.

Ha, Y. ve Im, H. (2012). Role of web site design quality in satisfaction and word of mouth generation. Journal of Service Management, 23(1), 79-96.

Hausman, A. V. ve Siekpe, J. S. (2009). The effect of web interface features on consumer online purchase intentions. Journal of Business Research, 62(1), 5-13.

Koç, H. İ. (2015). Üniversitelerde web sitelerinin kurumsal iletişim amaçlı kullanımı: Devlet ve vakıf üniversitelerinin web siteleri üzerine karşılaştırmalı bir analiz. Gümüşhane Üniversitesi Iletişim Fakültesi Elektronik Dergisi, 3(2), 61.

Okay, A. ve Güçdemir, Y. (2011). Halkla ilişkilerde internet uygulamaları: Bugüne ve geleceğe dair bir bakış. M. Işık ve M. Akdă̆ (ED.), Dünden Bugüne Halkla İliş̧kiler içinde. Eğitim Kitabevi, Konya.

Özçelik, E., Kurşun, E., ve Çağiltay, K. (2006). Göz hareketlerini izleme yöntemiyle üniversite web sayfalarinin incelenmesi. Akademik Bilişim 2006 içinde.

Soummakie, B. ve Talay, İ. (2020). Efficiency and performance measurement of Turkish universities via data envelopment analysis. Hacettepe Üniversitesi İktisadi ve İdari Bilimler Fakültesi Dergisi. 38(1), 115-138.

Suleiman, M. H. ve Loai F. Al-Zoua'bi. (2008). Usability of the academic websites of Jordan's universities an evaluation study. In: Proceedings of the 9th International Arab Conference for Information Technology, 31-40.

Tarhan, A. (2007). Halkla ilişskilerde tanıma ve tanıtma aracı olarak internet. Selçuk İletişim Dergisi, 4(4), 75-95.

University of Maryland. (2007). UM Library's web site usability testing. http://www.lib.umd.edu/itd/ux/site07/index.html Erişim Tarihi: 25.12.2020

VandeCreek, L. M. (2005). Usability analysis of Northern Illinois University Libraries' Website: A case study. OCLC Systems \& Services: International Digital Library Perspectives. 